\title{
INVESTIGATING CONTRIBUTING FACTORS TO STRESS AMONG MATHEMATICS LECTURERS IN HIGHER INSTITUTIONS OF LEARNING IN OYO STATE, NIGERIA
}

\author{
Kamoru Abiodun Sabitu ${ }^{1}$, Michael Adeyinka Kehinde ${ }^{2}$ \\ ${ }^{1}$ Department of General Studies, ${ }^{2}$ Department of Mathematics, \\ ${ }^{1,2}$ Federal College of Education (Special) Oyo, Oyo State, Nigeria. \\ *Corresponding author: sabitcamor@gmail.com \\ ORCID ID:(i) https://orcid.org/0000-0002-8727-1676
}

Received: $23^{\text {rd }}$ July, 2020; Revised: $01^{\text {st }}$ August, 2020; Accepted $16^{\text {th }}$ August, 2020

ABSTRACT
Introduction: This study investigated some contributing factors to stress among mathematics lecturers in higher institutions of learning in Oyo state, Nigeria.

Purpose: The study was to find out the contributions of cognitive, intrinsic and systemic factors in causing stress among mathematics lecturers in higher institutions.

Methodology: The study adopted a survey research design. The population of the study covered mathematics lecturers in ten (10) selected higher Institutions of learning in Oyo State, Nigeria. Simple random sampling technique was used in the selection of one hundred (100) mathematics lecturers, ten (10) lecturers per institution participated in the study. A self-designed structured questionnaire was used to collect data from the participants in the study. Croabach alpha was used to attain Correlation Coefficient $(r=0.88)$ which made the instrument reliable for the study. Three hypotheses were tested using the Chi square statistic at 0.05 level of significant.

Results: Findings revealed that cognitive factors did affect individual Mathematics lecturer with $x^{2}$-tab $(21.0)<x^{2}$-cal (183.31). Also, intrinsic factors do affect the level of stress among Mathematics lecturers with $x^{2}$-tab $(21.0)<x^{2}$-cal $(86.84)$, while systemic factors within the school setting did affect stress among Mathematics with $x^{2}$-tab $(21.0)<x^{2}$-cal (91..62).

Recommendations: Based on findings of the study, it was recommended among others that management of higher institutions of learning should encourage mathematics lecturers to go for break and relaxation every day during break period on the academic time table.

Keywords: Contributive factors, Higher-Institutions, Lecturers, Mathematics, Stress

Cite paper as:

Crossref Sabitu, K. A., \& Kehinde, M. A. (2020). Investigating contributing factors to Cited-by stress among mathematics lecturers in higher institutions of learning in Oyo state, Nigeria. Journal of Educational Research in Developing Areas, 1 (1), 50-56. https://doi.org/10.47434/JEREDA.1.1.2020.50

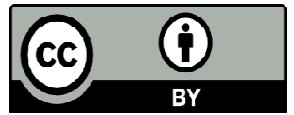

Copyright (c) 2020 The author(s) of this article retain(s) the copyright.

\section{PUBLIC INTEREST STATEMENT}

This study provides useful information about stress and its implications on performance of Mathematics lecturers in higher institutions of learning in Oyo state. Individual lecturer will know how cognitive, intrinsic and systemic factors affect their performances. The educational planners too will find the results useful in the planning educational programmes and guide the management of higher institutions in planning academic time table. 


\section{INTRODUCTION}

Stress is a normal psychological and physical reaction to the demands of life (Haider, 2012). A small amount of stress can be good, motivating one to perform well, but multiple challenges daily such as sitting in traffic, meeting deadlines and paying a bill can push one beyond ability to cope. Brain comes hard-wired with an alarm system for protection. When your brain perceives a threat, it signals your body to release a burst of hormones that increase your heart rate and raise your blood pressure. This "fight-or-flight" response fuels you to deal with the threat (Krathwohl, 2012). According to Derogatis (2001), stress is defined as a state of psychological pressure influenced by three main sources or domains: personality mediators (put together of time pressure, driven behaviour, attitude posture, relaxation potential, and role definition); environmental factors (constituting of vocational satisfaction, domestic satisfaction, and health posture); and emotional responses (such as hostility, anxiety, and depression). Too much stress can result to health problems.

Chan (2008) opined that stress can also reduce the ability to perform at the highest levels. The negative effects of stress have negatively on performance and quality of life. The effects of stress are many which include increased heart rate, speed breathing or held breath, tightens muscle to prepare to fight or to flee, directing blood to the brain and major muscles (away from digestion, hands/feet, reproductive organs), releases stress hormones like cortisol and adrenaline, slows or stops digestion, causes the brain to be more reactive/less thoughtful, increases perspiration, reduces immune system response (Guglielmi \& Tatrow, 2008). Tension headaches, neck pain, back pain, shoulder pain, tight jaw, sleeping problems, fatigue, loss of concentration, learning problems can increase irregular or rapid heart rate, migraine headaches, poor circulation, Raynaud Syndrome, high blood pressure, sexual dysfunction (in either sex), digestive problems, upset stomach, ulcers, colitis, hormone imbalances, reduction of immune system function, overreaction by the immune system (allergies or autoimmune diseases worse), increased asthma activity, increased ageing rate, anxiety, depression, substance abuse, poor habit control, over-eating, low energy, prone to accidents or mistakes, can impair communication, poor performance, among other effects are characteristics of stress (Guglielmi \& Tatrow, 2008).

Lecturer stress can be defined as a lecturers' experience of unpleasant, negative emotions resulting from some aspects of their work (Sternberg, 2016). Lecturer stress consists of two components which are stress causes and stress responses. Stress causes are the collection of aspects of the work content and the work situation influencing employees at cognitive, motivational and emotional levels. Stress responses are the employees' mental interpretations when experiencing stress causes. The psychological strain can lead to negative organizational outcomes like poor performance, health-related problems and absenteeism. Lecturers deal with a wide variety of stress causes daily. The number of stress causes for lecturers, including high job demands, students' misbehaviour, poor working conditions, poor relationships at work, role conflict, role ambiguity, lack of autonomy, poor school ethos and lack of developmental opportunities (Travers \& Cooper 2007). Mathematics lecturers stress is a much talked of a phenomenon, however, there is little consensus between different professional groups regarding its aetiology, or how to tackle it. The understanding of stress originated in the empirical research of Derogatis (2001) who conducted research using the Derogatis Stress Profile (DSP), a psychological questionnaire to measure individuals' stress dispositions. Derogatis based this questionnaire on Lazarus's (2006) social interaction theory of stress which consequently led us towards Lazurus's more recent research and theories of stress and how to cope with it. Lazarus \& Folkman (2004) define stress as a particular interaction between the mathematics lecturers and the environment. Mathematics lecturers appraised or evaluated the environment as being taxing or exceeding his or her resources. This disrupts his or her daily routines.

Some researchers suggested that several stressors are intrinsic to teaching. Travers \& Cooper (2007) found out that the workload and long working hours emerged as particular issues for mathematics 
teachers as opposed to colleagues in France. When Travers \& Cooper (2007) questioned British teachers across all educational sectors high workload, poor status and poor pay emerged as three of the seven major sources of stress, the others being systemic in origin. A study by Male \& May (2008) of learning support coordinators in further education colleges further illustrates the importance of these factors.

\section{STATEMENT OF PROBLEM}

The sources of stress experienced by a particular Mathematics lecturer will, of course, be unique to him/her and will depend on the precise complex interaction between his/her personality, values, skills, and circumstances. Moreover, coping mechanisms, personality traits, or the environment can interactively influence the degree to which stressful situations are being perceived, and influence the teacher's emotional and cognitive wellbeing. The syndrome of burnout and stress at work refers to a combination of emotions, physical symptoms and behaviours that develop as a consequence of the conditions and characteristics of the so-called helping professions. Although stress always involves a transaction between the individual and their environment, for heuristic purposes, causal factors in Mathematics stress can be divided into three broad areas: factors intrinsic to teaching, cognitive factors affecting the individual vulnerability of teachers and systemic factors operate at the institutional and political level. Workload also contributed to the stress of mathematics lecturers. This work found out the factors that contributed to stress for mathematics lecturers in the higher institutions in Oyo State.

PURPOSE OF THE STUDY:

The purpose of this study is to:

1. find the contribution of cognitive factors in causing stress among mathematics lecturers in higher institutions.

2. determine the extent to which intrinsic factors cause stress among mathematics lecturers in higher institutions.

3. establish whether systemic (organizational) factors within the school setup enhance stress of mathematics lecturers in higher institutions.

\section{HYPOTHESIS}

The following hypotheses were formulated and tested during the research.

$\mathrm{HO}_{1}$ : Cognitive factors do not affect the individual mathematics lecturer in higher institutions of learning in Oyo State.

$\mathrm{HO}_{2}$ : Intrinsic factors to teaching (workload, poor pay, classroom discipline and the low status) do not affect the level of stress among mathematics lecturers in higher institutions of learning in Oyo State.

$\mathrm{HO}_{3}$ : Systemic (organizational) factors within the school setting do not affect stress among mathematics lecturers in higher institutions of learning in Oyo State.

\section{METHODOLOGY \\ Research Design}

The research design adopted for this study was a descriptive design. This research design was chosen because it reports things the way they are and also specified who and what are to be measured.

\section{Population \& Sample}

The population of this study consisted of all lecturers in mathematics department of the ten (10) selected higher institutions of learning in Oyo State. Samples of ten (10) lecturers were selected from each school to make a total of one hundred (100). The schools selected are as follows:

1. University of Ibadan, Ibadan

2. Lead City University, Ibadan

3. Ajayi Crowther University, Oyo

4. The Polytechnic, Ibadan

5. The Polytechnic, Saki

6. Federal College of Education (Special), Oyo

7. Emmanuel Alayande College of Education, Oyo

8. Emmanuel College of Education, Lanlate

9. Federal School of Surveying, Oyo and

10. Oyo State College of Agriculture, Igbo Ora. 
These samples were selected by simple random sampling technique. Ballot papers inscribed with yes and no was made and lecturers that picked yes were selected. Male had the highest representation in the research work that is, $74 \%$ which showed that there are more male Mathematics lecturers in higher institutions of learning in Oyo state than their female counterparts with $26 \%$. Majority of the respondents were Masters' degree holders with $47 \%$ followed by $\mathrm{PhD}$ holders with $29 \%$ while the remaining $24 \%$ which fell majorly within the Polytechnics and Colleges of Educations.

\section{Instrument for Data Collection}

The instrument used for this study was a research self-designed structured questionnaire. The questionnaire was divided into two parts. The first part contained the demographic data while the second part contained the items on the subject matter where four Likert was used. Five (5) relevant questions were raised on each parameter. To ascertain the validity of the instrument, it was given to two experts in the field of test and measurement in Federal College of Education (Special), Oyo State. For reliability, it was administered on samples selected from the school of science, Federal College of Education (Special), Oyo, Oyo state. Croabach alpha was used to determine the reliability coefficient that gives 0.88 which is considered to be reliable.

\section{Procedure of Data Analysis}

Permission was sought from the heads, mathematics department of the schools under study. After approval from the heads of department, ballot papers were made which comprises of yes or no. the first five mathematics lecturers that picked yes were selected from each of the ten schools to make one hundred (100) samples for the research. The instrument were collected and collated for analysis.

\section{Method(s) of Data Analysis}

The data were analyzed using the chisquare statistic at 0.05 level of significant to test the hypothesis while the demographic data were analyzed using a simple percentage.

\section{RESULTS}

The results were organized in accordance with the hypotheses as follow:

Hypothesis 1: Cognitive factors do not affect the individual Mathematics lecturer in Higher Institutions of learning in Oyo State.

Table 1: Chi-Square test statistic of cognitive factors

\begin{tabular}{|c|c|c|c|c|c|c|c|}
\hline RESPONSES & $\begin{array}{l}\text { OBSERVED } \\
\text { VALUE }\end{array}$ & $\begin{array}{l}\text { EXPECTED } \\
\text { VALUE }\end{array}$ & DF & $\begin{array}{l}\mathrm{X}^{2} \\
\text { CALCULATED }\end{array}$ & $\begin{array}{l}X^{2} \\
\text { CRITICAL } \\
\text { VALUE }\end{array}$ & $\mathbf{P}$ & DECISION \\
\hline $\begin{array}{l}\text { STRONGLY } \\
\text { AGREE }\end{array}$ & 33 & 20 & \multirow{5}{*}{12} & \multirow{5}{*}{$183.31^{\mathrm{a}}$} & \multirow{5}{*}{21.0} & \multirow{5}{*}{0.05} & \multirow{5}{*}{$\begin{array}{l}\text { Reject the } \\
\text { null } \\
\text { hypothesis }\end{array}$} \\
\hline AGREE & 42 & 20 & & & & & \\
\hline NEUTRAL & 12 & 20 & & & & & \\
\hline DISAGREE & 6 & 20 & & & & & \\
\hline $\begin{array}{l}\text { STRONGLY } \\
\text { DISAGREE }\end{array}$ & 7 & 20 & & & & & \\
\hline
\end{tabular}

The table above shows that $\chi^{2}$-tabulated (21.0) is less than $\chi^{2}$ - calculated (183.31). Therefore, we reject the null hypothesis that cognitive factors do not affect the individual lecturer in Higher Institutions in Oyo state.
Hypothesis 2: Intrinsic factors to teaching (workload, poor pay, classroom discipline and the low status) do not affect the level of stress among Mathematics lecturers in Higher Institutions of learning in Oyo State. 
Journal of Educational Research in Developing Areas (JEREDA)

Vol. 1. Issue 1, Pp. 50-56, Inaugural Edition, 2020

http: / / www.jeredajournal.com

E-mail: info@jeredajournal.com

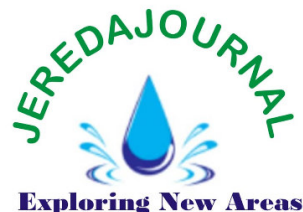

Table 2: Chi-Square test statistic of the intrinsic factors

\begin{tabular}{llllllll}
\hline RESPONSES & $\begin{array}{l}\text { OBSERVED } \\
\text { VALUE }\end{array}$ & $\begin{array}{l}\text { EXPECTED } \\
\text { VALUE }\end{array}$ & DF & $\begin{array}{l}X^{2} \\
\text { CALCULATED }\end{array}$ & $\begin{array}{l}X^{2} \\
\text { CRITICAL } \\
\text { VALUE }\end{array}$ & PECISION \\
$\begin{array}{l}\text { STRONGLY } \\
\text { AGREE }\end{array}$ & 42 & 20 & & & & \\
AGREE & 31 & 20 & & & & \\
NEUTRAL & 10 & 20 & 12 & $86.84^{\text {a }}$ & 21.0 & 0.05 & $\begin{array}{l}\text { Reject the } \\
\text { null } \\
\text { hypothesis }\end{array}$ \\
$\begin{array}{l}\text { DISAGREE } \\
\text { STRONGLY } \\
\text { DISAGREE }\end{array}$ & 11 & 20 & & & & \\
\hline
\end{tabular}

The table above shows that $\chi^{2}$-tabulated (21.0) is less than $\chi^{2}$ - calculated (86.84). Therefore, we reject the null hypothesis that intrinsic factors to teaching (workload,

Hypothesis 3: Systemic (organizational) factors within the school setting do not affect stress among Mathematics lecturers poor pay, classroom discipline and the low status) do not affect the level of stress among Mathematics lecturers in Higher Institutions in Oyo State.

in Higher Institutions of learning in Oyo State.

Table 3: Chi-Square test statistic of the systemic factors

\begin{tabular}{|llllllll|}
\hline Responses & $\begin{array}{l}\text { Observed } \\
\text { Value }\end{array}$ & $\begin{array}{l}\text { Expected } \\
\text { Value }\end{array}$ & $\begin{array}{c}\text { Df } \\
X^{2} \\
\text { Calculated }\end{array}$ & $\begin{array}{l}X^{2} \text { Critical } \\
\text { Value }\end{array}$ & Pecision \\
\hline $\begin{array}{l}\text { STRONGLY } \\
\text { AGREE }\end{array}$ & 31 & 20 & & & & \\
AGREE & 28 & 20 & & & & & \\
NEUTRAL & 10 & 20 & 12 & $91.62^{\mathrm{a}}$ & 21.0 & 0.05 & $\begin{array}{l}\text { Reject the } \\
\text { null } \\
\text { hypothesis }\end{array}$ \\
$\begin{array}{l}\text { DISAGREE } \\
\text { STRONGLY } \\
\text { DISAGREE }\end{array}$ & 9 & 20 & & & & \\
\hline
\end{tabular}

The table above shows that $\boldsymbol{\chi}^{2}$-tabulated (21.0) is less than $\chi^{2}$ - calculated (91.62). Therefore, we reject the null hypothesis that systemic (organizational) factors within the school setting do not affect stress among lecturer in Higher Institutions in Oyo State.

Volume 1, Number 1 (Inaugural Edition)

\section{DISCUSSION}

Table 1 showed that $\chi^{2}$-tabulated (21.0) is less than $\chi^{2}$ - calculated (183.31). Therefore, the null hypothesis was rejected that cognitive factors do not affect the individual lecturer in higher institutions of learning in Oyo state. The result goes along with the view of Guglielmi \& Tatrow (2008) and Lubart (2010) that a balanced mind $54 \mid \mathrm{P}$ a g e 
Journal of Educational Research in Developing Areas (JEREDA)

Vol. 1. Issue 1, Pp. 50-56, Inaugural Edition, 2020

http://www.jeredajournal.com

E-mail: info@jeredajournal.com

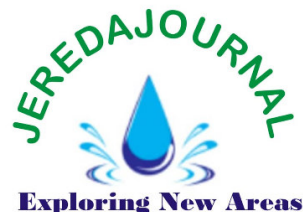

has a great influence on lecturer's performance. It is only when a lecturer is cognitively balanced especially, mathematics lecturers that he/she can concentrate on what to teach or instruction to pass.

Table 2 revealed that $\chi^{2}$-tabulated (21.0) is less than $\chi^{2}$ - calculated (86.84). Then, we reject the null hypothesis that intrinsic factors to teaching (workload, poor pay, classroom discipline and the low status) do not affect the level of stress among Mathematics lecturers in higher institutions of learning in Oyo State. The result goes along with the view of Travers \& Cooper (2007) that the condition in which a mathematics lecturer works contribute greatly to the level of stress. If a Mathematics lecturer is overloaded with work and the pay does not correlate with the volume of work done, the lecturer tends to get stressed up and his/her performance will be affected. Also, the motivation is another intrinsic factor which is very important. When mathematics teachers are overlaboured and are well motivated, they will not experience stress because the motivation as intrinsic factor will work with the cognitive factor which will reduce the burden and overcome any stress, but if they are not motivated, stress will manifest and less output will be experienced (Sternberg, 2016; Lazarus \& Folkman, 2004).

Table 3 showed that $\boldsymbol{\chi}^{2}$-tabulated (21.0) is less than $\chi^{2}$ - calculated (91.62). Therefore, we reject the null hypothesis that systemic (organizational) factors within the school setting do not affect stress among mathematics lecturer in higher institutions of learning in Oyo State. The result goes in line with the view of Male \& May (2008); Starko (2014) and Tanggaard (2014) that organizational factor-like leadership style used in the school contributes to the stress encountered by mathematics lecturers. An autocratic system of leadership tends to make mathematics lecturers work under duress which may deter them from delivering service with their full ability and capability. Other systematic factors are studentteacher ratio in the classrooms, school location and environment and so on. If the mentioned factors are not properly guided, it may contribute immensely to Volume 1, Number 1 (Inaugural Edition)

mathematics teachers' stress. This submission is in line with the view of Guglielmi and Tatrow (2008) who submitted that systemic factor contribute immensely to mathematics lecturers' stress in higher institutions of learning.

\section{CONCLUSION}

This research has shown that overwork, long working hours, discipline and evaluation apprehension have been identified as intrinsic stressors in teaching. There has been little or no research into the effects of reducing or mediating them, in part, because they are determined at a national level and are not easily open to experimental manipulation. Systemic factors are important in the aetiology of stress but do not easily lend them to manipulation to reduce it. Again, outcome studies for attempted strategies are lacking. The limitations of using the existing research base to plan stress-management in the country's education are compounded by other factors. Studies may not generalize well across education sectors and the base of cross-national and crosssector comparisons is inadequate to make judgments as to when generalization is justified. This study provides useful information about stress and its implications on the performance of mathematics lecturers in higher institutions of learning in Oyo state. Individual lecturers will know how some factors like cognitive factor among others affect their performances and how to prevent it. The educational planners too will find the results useful in the planning educational processes.

\section{RECOMMENDATIONS}

Based on the findings of this study, the following recommendations are made;

1. Stress management should be introduced as a course to the curriculum of teacher education programme in Nigeria.

2. Management of higher institutions of learning should encourage mathematics lecturers to go for break and relaxation every day during break period on the academic time table. 
Journal of Educational Research in Developing Areas (JEREDA)

Vol. 1. Issue 1, Pp. 50-56, Inaugural Edition, 2020

http://www.jeredajournal.com

E-mail: info@jeredajournal.com

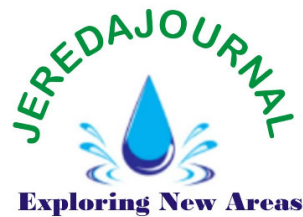

3. Special allowances should be set aside by the authority for mathematics lecturers, considering their nature of Works.

4. Workshops and seminars should be organized time to time on health talk and purpose of relaxation for mathematics lecturer in higher institutions of learning.

Conflicts of Interest: The authors declare no conflict of interest.

Acknowledgments: The researchers acknowledged the Heads and Lecturers of mathematics department of the following schools for their cooperation during the collection of data: University of Ibadan, Ibadan, Lead City University, Ibadan, Ajayi Crowther University, Oyo, The Polytechnic, Ibadan, The Polytechnic, Saki, Federal College of Education (Special), Oyo. Others are Emmanuel Alayande College of Education, Oyo, Emmanuel College of Education, Lanlate, Federal School of Surveying, Oyo and Oyo State College of Agriculture, Igbo Ora.

\section{Notes on Authors}

Kamoru Abiodun Sabitu is a Lecturer III in the Department of General Studies Education, Federal College of Education (Special), Oyo. His area of research interest is Mathematics Education.

Michael Adeyinka Kehinde is senior lecturer in the Department of Mathematics, School of Secondary Education (Science Programmes), Federal College of Education (Special) Oyo, Oyo State.

\section{Authorship and Level of Contribution}

Kamoru Abiodun Sabitu is the Principal Author. He led the research team. He played active role in validation and reliability testing of instrument, data collection and analysis.

Michael Adeyinka Kehinde sought the permission of the heads of department, took part in collection and analysis of data.

\section{REFERENCES}

Chan, L. V. (2008). Statistical methods for meta-analysis. Academic Press.

Derogatis, D. R. (2001). Practical metaanalysis. Sage.

Guglielmi, R. S., \& Tatrow, K. (2008). Occupational stress, burnout, and health in teachers: A methodological and theoretical analysis. Review of Educational Research, 68(1), 61-99.

Haider, Z. (2012). Professional teacher for 21st century. Journal of Engineering, Science \& Management Education, 5(11), 480-482.

Krathwohl, D. R. (2012). A revision of bloom's taxonomy: An overview. Theory into Practice, 41(4), 212218.

Lazarus, R. S. (1966). Psychological stress and the coping process. McGraw- Hill Book Company.

Lazarus, R. S., \& Folkman, S. (2004). Stress, appraisal, and coping. Springer.

Lubart, T. (2010). Cross-cultural perspectives on creativity. In J. C. Kaufman \& R. J. Sternberg (Eds.), Cambridge University Press.

Male, A. S., \& May H. I. (2008). Teacher stress: Directions for future research. Educational Review, 53(1), 27-35.

Tanggaard, L. (2014). A situated model of creative learning. European Educational Research Journal, 13(1), 107-116.

Travers, S. C., \& Cooper, M. C. (2007). Effectiveness of hardiness, exercise and social support as resources against illness. Journal of Psychosomatic Research, 2(9), 525-533.

Starko, A. J. (2014). Creativity in the Classroom: Schools of curious delight (5th Ed.). Routledge.

Sternberg, R. J. (2016). The assessment of creativity: An investment-based approach. Creativity Research Journal, 24(1), 3-12. 